FEDERAL RESERVE BANK CLEVELAND

||||||||||||||||||||||||||

|||||||||||||||||||||||||||||

ๆ60454

WORKINC PAPERS

NUMBER 7601

Measuring the Service Return on Demand Deposits

Edward J. Stevens

Federal Reserve Bank of Cleveland 
HE2613

C $64 F 45$

c. 1

MEASURING THE SERVICE RETURN ON DEMAND DEPOSITS

\author{
Edward J. Stevens \\ Senior Economist \\ Federal Reserve Bank of Cleveland \\ December 1976
}

The views expressed herein are solely those of the author and do not necessarily represent the views of the Federal Reserve Bank of Cleveland. The material contained is of a preliminary nature, is circulated to stimulate discussion, and is not to be quoted without permission of the author. 


\section{MEASURING THE SERVICE RETURN ON DEMAND DEPOSITS}

\section{E. J. Stevens*}

Changes are coming in the payments system of the United States, resulting from new electronic systems and new institutional and regulatory arrangements. Demand deposit balances are likely to be affected by these changes. How vulnerable are demand deposit holdings to the kinds of changes that can be foreseen? How large a shift in holdings should be expected as electronic devices such as automated clearinghouses and debit card networks, and institutional innovations such as NOW accounts become available? Because demand deposits represent a significant component of the monetary aggregates employed in monetary policy control decisions and operations, quantified answers to such questions are needed in order to know whether, and how substantial a change in monetary policy procedures might be required to maintain policy effectiveness.

Investigation of reasons for holding demand balances quickly reveals a disparity between economic theory embodied in aggregate money demand estimation and the institutional characteristics of the money market. Transaction demand modeling of the demand for money balances emphasizes that a noninterest-bearing cash balance of a certain size is held because the extra cost of more frequent transactions required to reduce that balance are greater than extra earnings on increased holdings of earning assets.

*Discussion with several of my colleagues at the Cleveland Bank and with Ben Klein were helpful in clarifying some of the matters included here. Gregory Suchocki provided valuable research assistance. Any errors in the paper, however, are mine. 
Corporations, on the other hand, hold large average demand deposit balances to compensate their banks for various services rendered. This suggests noninterest-bearing demand deposits earn an implicit service return. Changes in the technology and institutions of the payments system might affect the service return, and the impact of payments systems changes on demand deposit holdings might be estimated by quantifying their effects on the service return.

This paper compares two measures of the service return on demand deposits in the U. S. banking system. The rationale of a measurable service return and a brief survey of some previous measures are discussed in the first section. The model underlying the measures being compared is explained in the second section. The comparisons are presented in the third section, and conclusions are drawn.

I. The Service Return

Free services ${ }^{l}$ compensate customers for holding demand balances that, in the absence of a legal prohibition, might earn interest. Some demand balances are held to compensate banks for services that would otherwise involve a fee. More generally, services provided without fee to holders of demand balances may be viewed as an implicit return on balances.

Demand deposits are money that depositors can draw out of accounts at will, and banking services are usually provided simply as part of an ongoing bank-customer relationship. The link between size of balance and quantity of service is therefore not likely to be as rigid as that between interest payments and the size of a savings deposit balance, for example. However, competition in banking markets would tend to enforce a dependable average relationship over time between services and balances in at least two ways. 
First, particularly for consumer and small business checking accounts where profitability monitoring of each account is not feasible, banks can monitor service costs and aggregate average balances in such accounts. A bank can modify the mix of free and fee services, and therefore the service return of each depositor and of the average depositor, in an effort to improve or maintain profitability. Also, depositors can compare the mix of free and fee services among banks, for example, by looking at service charges and minimum balance requirements, seeking the highest service return on the average balance they would be likely to hold.

Second, particularly for large corporate and institutional depositors, the relationship between a bank and a depositor normally involves an informal or formal understanding about the mix of free and fee services provided as well as the average balance that the depositor will maintain. Periodic monitoring of each customer relationship will surface deviations from the initial understanding and signal the need for more rigorous enforcement or a new understanding.

Both of these processes describe how competition in the banking market will tend to produce a dependable average relationship between free services and demand balances that can be called the service return. The service return offered at competing banks to a given type of customer should tend toward a common value.

The inducement for customers to hold balances can thus be thought of as a combination of the productivity of balances as an inventory of funds from which to make payments and of the banking services that average balances entitle their holder to receive. A depositor targets an average balance because, at the margin, this combined value of a dollar in a demand account is greater than the interest he could earn on a dollar switched to an earning asset (net of any brokerage fee involved). 
Estimating the service return on demand deposits requires a measure of banking services provided without fee to holders of demand balances. Increasingly both banker and customer have an explicit measure of both services and balances, as banks develop more refined account profitability analysis procedures that monitor a customer's use of a full range of banking services as well as the size of his balances. ${ }^{2}$ However, only a limited number of banks participate in a system that compiles information for banks. ${ }^{3}$ Therefore, estimates of an aggregate or average service ratio might better be derived from indirect evidence.

Measures approximating all or part of the service return have been derived in the past. Yaari [8] estimated remitted (in the sense of 'forgiven') loan rate and service charges for a class of customers of a Chicago bank in 1968. Barro and Santomera [1] estimated remitted service charges on checking accounts at 23 banks annually from 1950 to 1968. O'Brien [7] estimated remitted activity costs on demand deposit accounts at First Federal Reserve District banks participating in the Functional Cost Analysis (FCA) program. Becker [2] constructed a measure using total noninterest expense, net of service charges and fees, per dollar of demand deposit for Federal Reserve member banks from 1952 through 1970.4

Becker's method, unlike the three other methods, recognizes the wide diversity of free services that may be included in the service return. FCA cost accounting information suggests that a broad range of services belongs in the service return. Four "nonbanking" activities are distinguished in the FCA data, covering customer services not directly involving deposits or assets. Income attributable to each of these activities is not sufficient to cover expenses of the activity in most 
cases (Table 1 ). One interpretation of this finding is that the nonbanking services are provided to customers in return for income attributable to those customers, but the income arises from other activities of the banks used by the customers. Becker's method attributes all noninterest expenses not covered by noninterest income, both of banking and nonbanking activities, to the demand deposit activity as a measure of the value of the return on demand deposits. B. Klein [3] uses a method that avoids Becker's assumption that all noninterest expenses in excess of fees are a return to holders of demand deposits, and Klein's method provides the starting point for this paper.

\section{Estimating the Service Return}

Suppose that all banks were perfect competitors in the deposit market where explicit interest payments are prohibited, entry is restricted by chartering, and aggregate deposits are controlled by the central bank's limited provision of reserves. Competition among banks for shares of this regulated demand deposit market should result in a marginal value of services per dollar of deposit, $\mathrm{rD}$, equal to banks' marginal earnings less the marginal cost of providing a deposit. Marginal cost, in turn, can be thought of as the sum of two components: (1) the loss incurred by lending at the loan rate, $r_{L}$, rather than acquiring a nonloan earning asset at "the" pure interest rate, i; (2) earnings foregone at the loan rate, $r_{L}$, on nonearning reserve assets that are equal to the ratio $r r$ of deposits. This combined marginal cost of supplying deposits, $\mathrm{MC}_{\mathrm{D}}$, is thus equal to $\left(i-r_{L}\right)+r_{L}(r r)$, or simply i-rL $(1-r r)$.

The price that depositors pay to hold a demand deposit and thereby acquire the productivity of money balances can be thought of as the difference between $i$, "the" interest rate on a pure nonmonetary asset, and $\mathrm{rD}_{\mathrm{D}}$, 
the service return on a demand deposit. In competitive equilibrium in the deposit market, this price paid by depositors, i-rD, should be equal to the marginal cost to banks of supplying demand deposits, i-rL(l-rr). Therefore, in equilibrium, $r_{D}=r_{L}(1-r r)$. That is, the market service return in equilibrium will be equal to the marginal loan rate on nonreserve assets financed by a marginal dollar of deposit. Competition among banks for market shares with explicit interest payments prohibited results in a 100 percent payout of marginal earnings on additional deposits in the form of banking services.

Estimating the value of $\mathrm{rD}$ is complicated by the realization that not all reserve assets of the banking system are acquired at the cost of lost earnings at the marginal loan rate. In particular, the banking system may acquire reserve assets at a "subsidy" rate via the discount window, via Fed float and government demand deposits (net of required reserves). 5 With these adjustments to $r_{D}$, reducing marginal cost and raising the service return, Klein's expression for estimating annual average $\mathrm{rD}$ is:

$$
r_{D}=r_{L}\left(1-r r_{D}\right)+r_{L} \cdot r r_{D}\left(\frac{G_{D D}-R_{G D D}}{R}\right)+\left(r_{L}^{w}-r_{d}^{W}\right)\left(r r_{D}\right)\left(\frac{B}{R}\right) \text {, }
$$

where:

$G_{D D}$ is U. S. Government demand deposits $\mathrm{R}_{\mathrm{GDD}}$ is reserves held on $\mathrm{G}_{\mathrm{DD}}$ $R$ is total reserve assets $r_{\mathrm{L}}^{\mathrm{W}}$ and $r_{\mathrm{d}}^{\mathrm{W}}$ are the average loan rate and discount rate weighted by monthly amounts borrowed during a year

$B$ is borrowing at the discount window $r \mathrm{D}$ is the demand deposit reserve ratio

Finding appropriate empirical counterparts of $r_{L}$ and $r r$ is the central problem in deriving a measure of $r_{D}$. 
Klein measured $\mathrm{rr}_{\mathrm{D}}$ from 1919 to 1972 by calculating reserves required against member bank time and savings deposits, and assuming excess reserves and nonmember vault cash were allocated to time deposits in proportion to the amount of time deposits in total deposits. 6 Subtracting these time deposit reserve holdings from $R$ gives a measure of reserves held against demand deposits which, when divided by demand deposits, is the measure of rrD used in both of the service ratios compared below.

Choosing the appropriate measure of $\mathrm{r}_{\mathrm{L}}$ is the problem underlying what follows. Klein's service ratio, $\mathrm{r}_{\mathrm{D}_{\mathrm{K}}}$, uses the yield on 4-6 month commercial paper, $r_{C P}$, as the measure of $r_{L}$, the marginal, or market, rate on earning assets financed by deposits. The alternative service ratio proposed here, $\mathrm{r}_{\mathrm{S}}$, uses the actual earnings rate on earning assets of all insured commercial banks, $r_{E}$, as the measure of $r_{L}$.

\section{Comparing Estimates}

Values of $r_{D_{K}}$ and $r_{D_{S}}$ for the years 1948-1974 are not the same (Chart 1 ). Differences arise solely from the measure of the market loan rate used. Which is the more appropriate measure?

Representativeness. A potential bias arises in $\mathrm{r}_{\mathrm{K}}$ because the yield on 4-6 month prime commercial paper may not be representative of the level of and annual change in rates on the range of assets financed by demand deposit liabilities. Commercial paper is a liquid marketable instrument issued by large corporations. Although the commercial paper rate has been clearly aligned with the average bank prime rate for the past decade, it was frequently significantly lower than prime before that. In addition, bank portfolios include a substantial proportion of real estate, consumer and small business loans whose rates are in general higher and more stable than the commercial paper rate (Table 2). Persistent differences in levels 
of rates among these markets reflecting different degrees of market power and lender's preferences might make the commerical paper rate a biased estimate of the average market rate earned on assets acquired by banks. ${ }^{7}$

Maturity. The average annual earnings rate on bank earning assets may not be the same as the average annual market rate at which assets are acquired. It may include the earnings rate on assets acquired in past years and retained in banks' portfolios. This bias would be smaller, the shorter the average original maturity of banks' portfolios and the more widespread the practice of setting floating rates on loans.

Recent changes in reporting requirements for banks now make it possible to measure remaining maturities for a large proportion of almost all categories of bank earning assets. In early 1976, 56 percent of the earning assets of large banks in the Fourth District either had remaining maturities of less than 1 year or had a maturity longer than 1 year but carried a floating rate. The original maturities of these assets is not known, but unless banks alter the maturity emphasis of their acquisitions substantially from year to year, shortest-term and floating rate assets must dominate original maturities: 44 percent of assets and 55 percent of loans had less than a 1-year maturity, only 34 percent of assets and 33 percent of loans had maturities of 1 to 5 years, and only 22 percent of assets and 12 percent of loans had a maturity longer than 5 years. In addition, 63 percent of loans with maturities longer than 1 year, representing 21 percent of long-term assets, carried a floating rate.

Because no comparable direct evidence is available historically, an assessment of the bias in $\mathrm{r}_{\mathrm{D}_{\mathrm{S}}}$ from the presence of aged assets in bank portfolios cannot be made. Whatever bias"may be present was probably more significant in earlier than in later years because of the declining 
proportion of securities in bank portfolios in the years after World War II. The level of $\mathrm{rD}_{\mathrm{S}}$ is probably biased downward, although by decreasing amounts over time, because the upward trend of interest rates over time generally would leave portfolios with aged assets at lower than current rates.

Comparing values $\mathrm{rD}_{\mathrm{K}}$ and $\mathrm{rD}_{\mathrm{S}}$ suggests that the downward bias from aged assets does not dominate the difference between the series. Until 1966 the value of $\mathrm{r}_{\mathrm{S}}$ was higher than $\mathrm{r}_{\mathrm{K}}$ in spite of the aged asset bias. Cyclical patterns in the difference do seem to reflect this bias. The excess of $\mathrm{rD}_{\mathrm{S}}$ over $\mathrm{rD}_{\mathrm{K}}$ peaks when market yields recede from cyclical peaks to cyclical troughs $(1950,54,58,61,67,72)$, apparently reflecting the retention of past peak earnings rates on aged assets in the average earnings rates of banks.

Preferential Rates. Preferential loan rates to holders of demand deposits is another potential source of bias in $\mathrm{rD}_{\mathrm{S}}$. Preferential rates commonly arise from formal or informal compensating balance arrangements in loan agreements. Such arrangements may be interpreted two ways. One view is that compensating balances are a portion of loan proceeds that cannot be used, raising the effective loan rate on the usable amount above the stated rate on the whole amount. The other view is that the compensating balance arrangement is a device to assure that balances rezognized in a preferential loan rate are not withdrawn by the customer once the loan agreement is formalized. In either case, the earnings rate of the bank on the book value of the loan is lower than the rate that would be charged on a loan without balances.

For the banking system as a whole, preferential loan rates reduce the observed earnings rate on earning assets relative to the "market" rate on loans. Without balance requirements, banks would lend $L_{N}$ at the market 
rate $r_{N}$, earning $R_{N}=L_{N} \cdot r_{N}$ in revenue. With balance requirements, banks would lend $\mathrm{L}_{\mathrm{B}}$. Each dollar of loan, L, would include a portion of L, $g$, required as a balance. This balance would then be reloaned so that $L_{B}=L+(g \cdot L)+g(g \cdot L)+\ldots+g^{n_{L}}=\frac{1}{1-g} \cdot L_{N}$. Lending $L_{B}$ at a preferential loan rate $r_{B}$ would generate earnings of $R_{B}=L_{B} \cdot r_{B}=\frac{1}{1-g} \cdot L_{N} \cdot r_{B}$. Assuming that the effective amount borrowed, $\mathrm{L}_{\mathrm{N}}$, and the revenue of lending, $\mathrm{R}_{\mathrm{N}}$, are independent of the way in which compensation is derived, the observed earning rate $r_{B}$, $=\frac{R_{N}}{L_{N} \cdot \frac{1}{l-g}}$, will be less than the rate $r_{N},=\frac{R_{N}}{L_{N}}$. If some earning assets involve a preferential rate and others do not, the observed earnings rate of banks, equal to earnings divided by earning assets, will lie between the preferential rate and the market rate.

Comparing $r_{K}$ and $r_{S}$ does not suggest that the bias of preferential rates dominates the difference between $r_{D_{K}}$ and $r_{D_{S}}: r_{S}$ exceeded $r_{K}$ in all but 4 of the years shown.

Risk. The prime commercial paper rate on which $\mathrm{rD}_{\mathrm{K}}$ is based should include only a modest risk premium because of the prime rating of issuers. The earnings rate, $r_{E}$, on which $r_{D_{S}}$ is based, includes interest income before losses on loans and securities, or any provision for future losses. The service return that a competitive banking system would provide would reflect earnings net of expected losses on loans; earnings could not for long cover services without some provision for covering losses.

Banks make provisions for losses, but reported provisions are not a suitable measure of expected loss. Reported provisions are distorted (for the purpose at hand) by tax regulations governing before-tax expenses allowed as a provision for loss. Significant changes in tax treatment and 
reporting requirements during the period included here make even the reported provisions noncomparable over time. Actual reported losses can be measured with greater consistency over time, but the annual incidence of reported loss is not an indicator of the annual expectation of losses.

Because $\mathrm{rE}_{\mathrm{E}}$ includes no allowance for expected losses, the $\mathrm{rD}_{\mathrm{S}}$ estimate is probably biased upward, overstating the service return in all years, and by an increasing percentage of the true service return because of the increasing porportion of more risky loans relative to less risky securities in bank portfolios.

Four sources of bias in $r_{D_{K}}$ and $r_{D_{S}}$ have been identified. $r_{D_{K}}$ is likely to be biased because it is not representative of the whole range of asset markets from which bank portfolios are drawn. $\mathrm{rD}_{\mathrm{S}}$ is likely to be biased upward because it does not allow for losses on risky earning assets, but is likely to be biased downward because it includes some earnings at a preferential rate and some earnings on aged assets. Clearly neither $\mathrm{rD}_{\mathrm{K}}$ nor $\mathrm{r}_{\mathrm{D}_{\mathrm{S}}}$ can be a completely trustworthy measure of the service return on commercial bank demand deposits. Two additional analytic tests can be used to discriminate between $\mathrm{rD}_{\mathrm{K}}$ and $\mathrm{rDS}_{\mathrm{S}}$ on the basis of their consistency with observed depositor and bank behavior.

Money Demand. What difference does it make which measure of the service return is used as an independent variable in explaining holdings of money balances? Klein has shown that demand for money can be expressed as a function of the price of obtaining money services from demand deposits balances, where price is measured by $\left(i-r_{D_{K}}\right)$. Substituting $r_{D_{S}}$ for $r_{D_{K}}$ in money demand equations using this approach may indicate that one or the other service return "works better," implying greater consistency with observed behavior. 
Klein's estimating equation for $M_{1}$ was of the form:

$M_{1}=a_{0}+a_{1} Y+a_{2} P_{S}+a_{3} P_{M}+u$, where

$\mathrm{M}_{1}=\log$ of real per capita $\mathrm{M}_{1}$ balances

$\mathrm{Y}=\log$ of real per capita net national product

$P_{S}=$ the price of securities, measured by the difference between the yield on long-term corporate bonds, $i$, and the yield on commercial paper, $r_{C P}$

$\mathrm{P}_{\mathrm{M}}=$ the price of money measured by $i-\mathrm{r}_{\mathrm{D}_{K}}$,

and linear regressions employed annual observations for the period 1919 through 1970.

Comparing the explanatory power of $r_{D_{S}}$ and $r_{D_{K}}$ in this form of money demand equation required two changes from Klein's original model. Klein's $\mathrm{r}_{\mathrm{D}_{\mathrm{K}}}$ was an annual series for the years 1919 through $1970 ; \mathrm{r}_{\mathrm{D}_{\mathrm{S}}}$ is only available as an annual series for the years 1948 through 1974. Therefore, $r_{D_{K}}$ was updated to 1974 , and the equation was estimated for the shorter sample period 1948 through 1974. Using this short sample period emphasizes adjustments of money balances to shorter-term variations of independent variables than in the original model. Addition of the lagged value of the dependent variable, $\mathrm{M}_{1}^{-1}$, to the estimating equation improved results. Aside from these related changes, the two money demand equations employing $\mathrm{r}_{\mathrm{D}_{\mathrm{K}}}$ and $\mathrm{r}_{\mathrm{D}_{\mathrm{S}}}$, respectively, are identical to Klein's original estimating equation and are shown in Table $3 .^{8}$

The results of this comparison are unilluminating--there is no statistically significant basis for choice between the estimating equations using $r_{D_{K}}$ and the alternative equation using $r_{D_{S}}$.

Bank Profits. If, as assumed in estimating the service return, 100 percent of bank earnings financed by demand deposits is paid out in bank services, then bank profits must arise from other aspects of banking. These can be traced to portfolio profits on assets financed by interest-bearing 
liabilities and equity, and profits on services sold for fees. That is, total profit, $\pi_{\mathrm{T}}$, is the sum of $\pi_{\mathrm{D}}$ on assets financed by demand deposits, $\pi_{B}$ on assets financed by interest-bearing liabilities, $\pi_{E}$ on assets financed by equity, and $\pi_{F}$ on services sold for fees. $\pi_{D}=\left[r_{L}\left(1-r_{D}\right)-r_{D}\right] D D$, and is assumed equal to $0 . \pi_{\mathrm{B}}=\left[r_{\mathrm{L}}\left(1-r r_{\mathrm{T}}\right)-r_{\mathrm{B}}\right] \mathrm{B}-\mathrm{X}_{\mathrm{B}}$, where $r r_{\mathrm{T}}$ is the average reserve ratio on interest-bearing liabilities, $B, r_{B}$ is the interest rate paid on $B$, and $x_{B}$ are noninterest expenses of acquiring the assets and purchased funds. $\pi_{E}=r_{L} \cdot E$, where $E$ is financing supplied by equity. $\pi_{F}=F-X_{F}$, where $F$ is fee income and $X_{F}$ is the expense of producing services sold for fees.

One test of the appropriateness of the two estimates of $\mathrm{r}_{\mathrm{D}}$ is to calculate $\pi$ setting $r_{L}$ equal to whichever measure of the loan rate is used in deriving an $r_{D}$, and setting $X=X_{B}+X_{F}$, equal to total noninterest expense of banks net of $r_{D} \cdot D D$, the estimated noninterest expense of services for holders of demand balances. The closer calculated profit, $\pi_{C}$, approximates actual bank profits, $\pi_{a}$, the more trustworthy would an $r_{D}$ measure seem to be. Table 4 shows the results of such an exercise using income and balance sheet data for all insured commercial banks. $\pi_{a}$ is defined as net current operating earnings before taxes, gains and losses and provisions for loss on securities and loans, and extraordinary charges. Two sets of results are shown. The first column reports the annual difference between $\pi_{C_{K}}$, calculated using $r_{C P}$ and $r_{D_{K}}$, and $\pi_{a}$, expressed as a percentage of $\pi_{a}$. The second column reports the analogous percentage for $\pi_{C_{S}}$, calculated using $r_{E}$ and $\mathrm{rD}_{\mathrm{S}} \cdot \pi_{\mathrm{c}_{K}}$ tends to understate $\pi_{a}$, and $\pi_{\mathrm{c}_{S}}$ tends to overstate $\pi_{a}$, on average, by 36 percent and 14 percent, respectively.

Some difference between $\pi_{C_{K}}$ and $\pi_{C_{S}}$ is to be expected because of biases attributed to unrepresentativeness, preferential loans rates, maturity, and 
risk. Potential biases associated with preferential loan rates and maturity of bank portfolios are not relevant to $\pi_{\mathrm{C}_{K}}$, but should bias $\pi_{\mathrm{C}_{S}}$ downward, and cannot explain why $\pi_{\mathrm{CS}}$ overstates $\pi_{\mathrm{a}}$, on average.

Differences that might be attributed to noncomparable treatment of risk can be quantified. $\pi_{a}$ is actual net current operating earnings of banks before any allowance for loss. $\pi_{C S}$ is derived from a measure of loan and deposit rates before any allowance for losses, and should be comparable to $\pi_{a}$. On the other hand, $\pi_{c_{K}}$ is derived from a measure of loan and deposit rates using the yield on prime commercial paper, a high quality relatively risk-free instrument. $\pi_{c_{K}}$ should only approximate actual profit after some allowance for losses. This might explain why $\pi_{\mathrm{C}_{\mathrm{K}}}$ understates $\pi_{\mathrm{a}}$, on average. The average amount of the expected understatement can be approximated by banks' reported losses on loans and securities (column 3), equal to 9.25 percent of average net current operating earnings for the period. This assumes that losses expected by bankers are validated by actual losses, although the approximation would not necessarily hold year by year. Expected losses are presumably what determines the marginal cost of deposits and the competitive service return banks can afford to pay. Deducting 9.25 percent from $\pi_{a}$ in every year and recalculating the annual difference between $\pi_{\mathrm{CK}_{\mathrm{K}}}$ and this adjusted value of $\pi_{a}$ reduced the average understatement of actual bank profit from 36 percent to 21 percent, expressed as a percentage of adjusted $\pi_{a}$. This unexplained residual difference may be a reflection of the bias contributed by using the unrepresentative commercial paper rate as a measure of the loan rate.

$r_{D_{S}}$ should be adjusted downward to reflect expected losses on loans and securities, but the only loss information is for actual losses. On average, losses equalled 6 percent of service return expense $\left(r_{D_{S}} \cdot D D\right)$ 
during the period 1948 through 1974. Applying this average percentage entirely to demand deposits through $\mathrm{r}_{\mathrm{D}_{\mathrm{S}}}$ would reduce the measured service return by a maximum of about 12 basis points in 1948 and about 47 basis points in 1974. Lacking any method of uniquely distributing losses among years, such an adjustment would leave the money demand and profit analys is comparisons of $r_{D_{S}}$ and $r_{D_{K}}$ unaffected.

Conclusions

Two measures of the service return on demand deposits have been compared.

1. Both measures are in general higher than previous estimates of the service return. Several previous estimates would be expected to understate service returns because they adopt one or another narrow definition of the form the return might take.

2. One other previous estimate, by Becker, takes a broad definition of the form of return and it, too, is in general lower than the two measures compared here. 9 This difference is attributed to a difference in assumptions. Becker assumes that all noninterest expense in excess of noninterest income is the expense of service return, and that there are no other noninterest expenses of banking. $r_{D_{S}}$ and $r_{D_{K}}$ are based on an assumption that all noninterest expense in excess of the expense of the service return $\left(r_{D} \cdot D D\right)$ is the combined expense of services sold for fees and other noninterest expenses of banking. The fact that Becker's measure is lower than $\mathrm{rD}_{\mathrm{S}}$ and $r_{D_{K}}$ indicates that $r_{D} \cdot D D$ is greater than actual noninterest expense net of fees, implying that, to the extent services are sold for fees, they yield profits. 
3. Both $r_{D_{S}}$ and $r_{D_{K}}$ are consistent with money demand estimates for the post-war period, but $\mathrm{r}_{\mathrm{D}_{\mathrm{S}}}$ appears to be a measure more consistent with actual bank profits before losses on loans and securities. 


\section{FOOTNOTES}

$\mathrm{I}_{\text {These }}$ might include account activity, cash mobilization, collection, bookkeeping, computer, money management, reduced loan rates, loan processing, informal credit line, foreign exchange, trust, investment, and economic advisory services.

${ }^{2}$ For discussion of account profitability analysis, see R. Knight, [4]; P. S. Nadler, [6].

${ }^{3}$ The system is the voluntary Functional Cost Analysis program of the Federal Reserve. A self-selected group of 862 member commercial banks furnished data in 1975.

$4^{4}$ Becker's estimates would need to be revised in three ways to make them comparable with the measures discussed below. His sample is member banks, rather than all insured banks. He divides annual net expense by yearend deposits, overstating the average level of deposits during a year. The measures below use an average of December-June and June-December averages. He uses gross demand deposits, double-counting deposits by the amount of cash items in process of collection. Each of these adjustments would raise the level of Becker's estimates of the service return.

${ }^{5} \mathrm{Klein}$ also adjusts for expected losses of deposits through bank failure, but the adjustment is zero for the years 1948 through 1974 studied here.

${ }^{6}$ Total deposits and total reserves are measured net of large CD's after 1961. This has the effect of assuming that only required reserves are held against large CD's.

7Lenders' preferences are assumed to be unrelated to their sources of funds. There is some evidence that the representative rate would vary among banks with different proportions of demand deposit financing. See, for example, Longbrake, [5] .

${ }^{8}$ Updating $r_{D_{K}}$ and calculating $r_{D_{S}}$ was made considerably easier by Professor Klein's kindness in supplying a complete set of his original data files.

9 Becker's estimate is in general lower than both $r_{D_{K}}$ and $r_{D_{S}}$ after making the three adjustments noted in footnote 4 , above. 


\section{BIBL IOGRAPHY}

[1] Barro, R. J. and A. M. Santomero, "Household Money Holdings and the Demand Deposit Rate," Journal of Money, Credit, and Banking, May 1972 .

[2] Becker, W. E., "Determinants of the United States Currency-Demand Deposit Ratio," Journal of Finance, March 1975.

[3] Klein, B., "Competitive Interest Payments on Bank Deposits and the Long-run Demand for Money," American Economic Review, December 1974.

[4] Knight, R., "Customer Profitability Analysis," Monthly Review, Federal Reserve Bank of Kansas City, March and September/October 1975.

[5] Longbrake, W. A., "Commercial Bank Capacity to Pay Interest on Demand Deposits, Part II: Earnings and Cost Analysis," Mimeograph, Federal Deposit Insurance Corporation, 1975.

[6] Nadler, P. S., "Compensating Balances and the Prime at Twilight," Harvard Business Review, January/February 1972.

[7] O'Brien, J. M., "Interest Ban on Demand Deposits: Victim of the Profit Motive?" Business Review, Federal Reserve Bank of Philadelphia, August 1972.

Yaari, U., "The Legal Payment of Illegal Interest on Demand Deposits," Mimeograph, Rutgers College. 
TABLE 1

RETURN: OTHER DEPARTMENTS--1975

\begin{tabular}{|c|c|c|}
\hline $\begin{array}{c}\text { Under } \\
\$ 50 \text { million } \\
\text { in deposits }\end{array}$ & $\begin{array}{l}\$ 50 \text { to } \$ 200 \\
\text { million } \\
\text { in deposits }\end{array}$ & $\begin{array}{l}\text { Over } \\
\$ 200 \text { million } \\
\text { in deposits }\end{array}$ \\
\hline
\end{tabular}

Safe Deposit (loss per box)

$\$ 4.8$

$\$ 5.1$

$\$ 5.9$

Trust

(loss per \$ of expense)

$35.4 \dot{c}$

$25.9 \xi$

15.1c

Computer

$5.9 \dot{c}$

$18.0 \xi$

23.0द

(loss per \$ of expense)

Other Nonbanking

(loss per \$ of expense)

$7.4 \zeta$

$12.8 \xi$

$-8.6 \dot{1}$

Source: Functional Cost Analysis: 1975 Average Banks 
TABLE 2

\section{PORTFOLIO COMPOSITION \\ ALL INSURED COMMERCIAL BANKS}

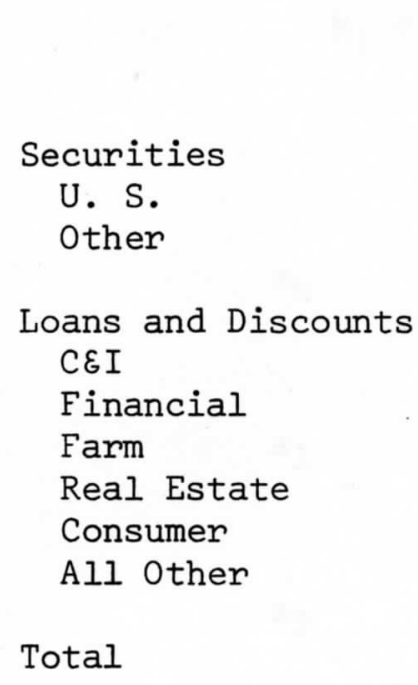

1948

(June 30)

$65 \%$

$57 \%$

8

35

16
2
2
9
5
1

$100 \% \quad 100 \%$
1960

(June 15)

$39 \%$

$29 \%$

10

61

22

7

3

15

13

1

$100 \% \quad 100 \%$
1974

(June 30)

$26 \%$

$12 \%$

14

74 25

12

3

18

14

2

$100 \% \quad 100 \%$

Source: FDIC Annual Report 
TABLE 3

\section{ALTERNATIVE DEMAND FOR MONEY} ESTIMATING EQUATIONS

$$
\begin{aligned}
M_{1}=a_{0}+a_{1} Y+a_{2} P_{S}+a_{3} P_{M}+a_{4} M_{1}^{-1}+u \\
P_{M}=i-r_{D_{K}} \quad \underline{P_{M}=i-r_{D_{S}}}
\end{aligned}
$$

$a_{0}$

$* \quad-0.21$

$-0.17$

$(0.08)$

$(0.10)$

$(2.46)$

(1.75)

$a_{1}$

$\begin{array}{cc}0.20 & 0.14 \\ (0.07) & (0.07) \\ (3.00) & (2.02)\end{array}$

$a_{2}$

$\begin{array}{ll}0.04 & 0.01 \\ (0.01) & (0.005) \\ (3.50) & (2.20)\end{array}$

$a_{3}$

$$
-0.05
$$

(0.02)

$-0.02$

(3.14)

$(0.01)$

$(2.07)$

$a_{4}$

$\begin{array}{cc}0.95 & 0.97 \\ (0.06) & (0.08) \\ (14.60) & (12.00)\end{array}$

$\overrightarrow{\mathrm{R}}^{2}$

0.9555

0.9461

F

140.7

115.2

D-W

2.04

1.91

$\sum u^{2}$

0.006

0.008

*First number is coefficient, followed (in parentheses) by standard error of coefficient and t-statistic. 
Table 4

SERVICE RETURNS AND BANK PROFITS*

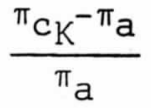

$-0.84$

$-0.86$

$-0.91$

$-0.40$

$-0.88$

$-0.42$

$-1.08$

$-0.71$

$-0.15$

$-0.01$

$-0.86$

$-0.10$

$-0.32$

$-0.83$

$-0.80$

$-0.67$

$-0.49$

$-0.30$

0.24

$-0.18$

0.13

0.76

0.45

$-0.70$

$-1.06$

0.55

0.77

$-0.36$

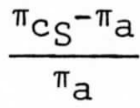

0.18

0.18

0.09

0.18

0.20

0.19

0.02

0.18

0.17

0.17

0.19

0.17

0.18

0.20

0.16

0.21

0.20

0.21

0.13

0.13

0.13

0.04

0.04

0.03

0.04

0.04

$-0.01$

0.14
Loss on Loans

and Securities

(mils. of \$)

$\$$

8.4

20.6

$-32.8$

67.7

115.2

211.2

$-260.4$

236.2

388.0

279.7

$-477.6$

763.2

117.7

$-164.5$

13.2

159.0

312.9

363.8

936.1

487.6

934.7

488.8

981.6

$1,087.2$

887.3

$1,159.2$

$1,956.9$

408.9

*See text for explanation. 


\section{FIGURE 1}

\section{TWO MEASURES OF SERVICE RETURN ON DEMAND DEPOSITS}

SERVICE RETURN RATE

PERCENT

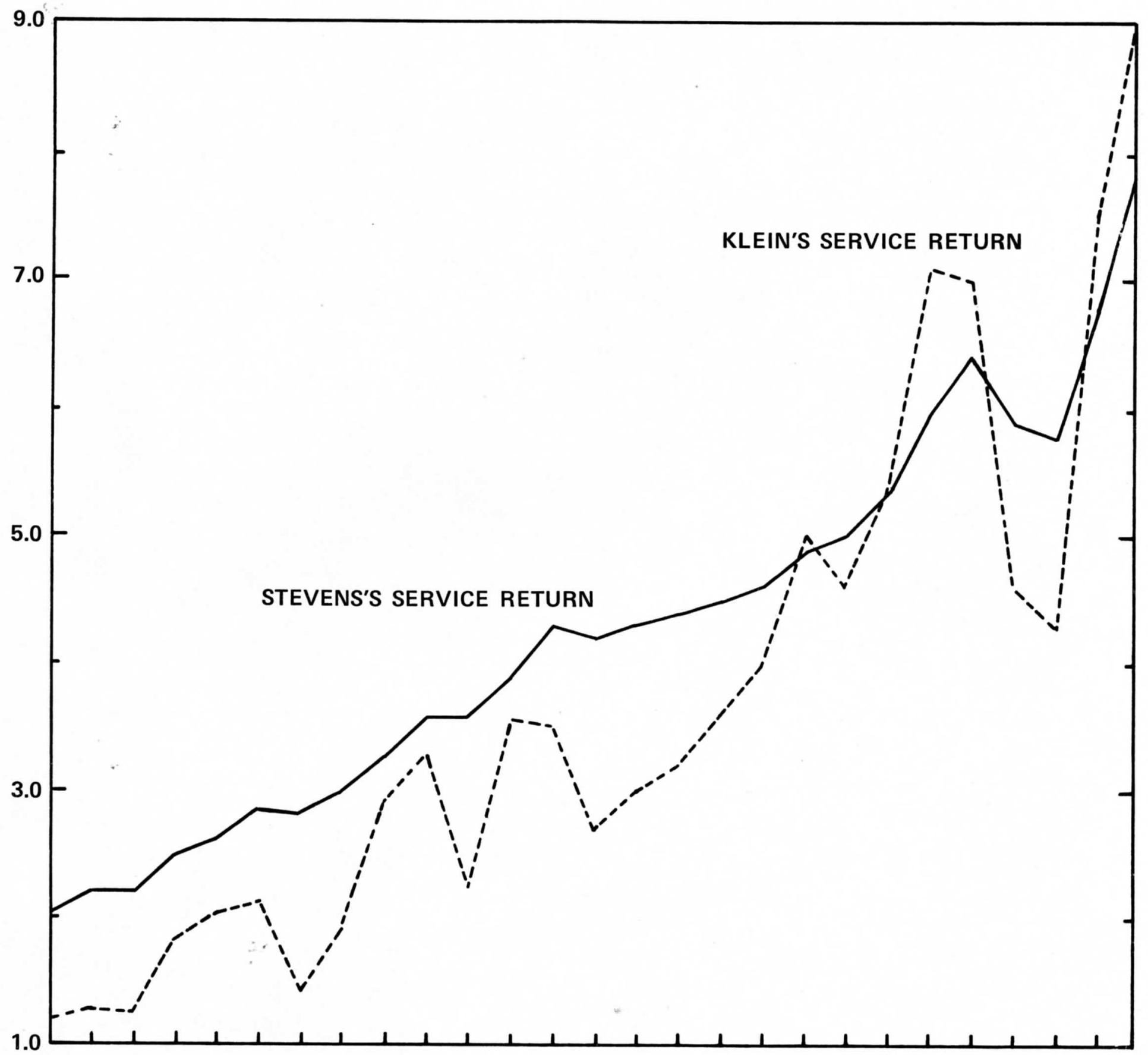

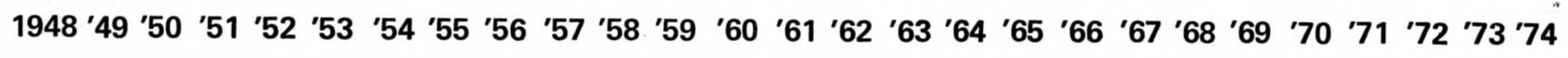

